\title{
The Santonio Project: An Archaeological Reconnaissance for Urex, Inc. Southeastern Webb County, Texas
}

Eric C. Gibson

Follow this and additional works at: https://scholarworks.sfasu.edu/ita

Part of the American Material Culture Commons, Archaeological Anthropology Commons, Environmental Studies Commons, Other American Studies Commons, Other Arts and Humanities Commons, Other History of Art, Architecture, and Archaeology Commons, and the United States History Commons

Tell us how this article helped you.

This Article is brought to you for free and open access by the Center for Regional Heritage Research at SFA ScholarWorks. It has been accepted for inclusion in Index of Texas Archaeology: Open Access Gray Literature from the Lone Star State by an authorized editor of SFA ScholarWorks. For more information, please contact cdsscholarworks@sfasu.edu. 
The Santonio Project: An Archaeological Reconnaissance for Urex, Inc. Southeastern Webb County, Texas

\section{Creative Commons License}

(c) (1) (8)

This work is licensed under a Creative Commons Attribution-NonCommercial 4.0 International License 


\section{THE SANTONINO PROJECT}

\section{An Archaeological Reconnaissance for Urex, Inc.}

\section{SOUTHEASTERN WEBB COUNTY, TEXAS}

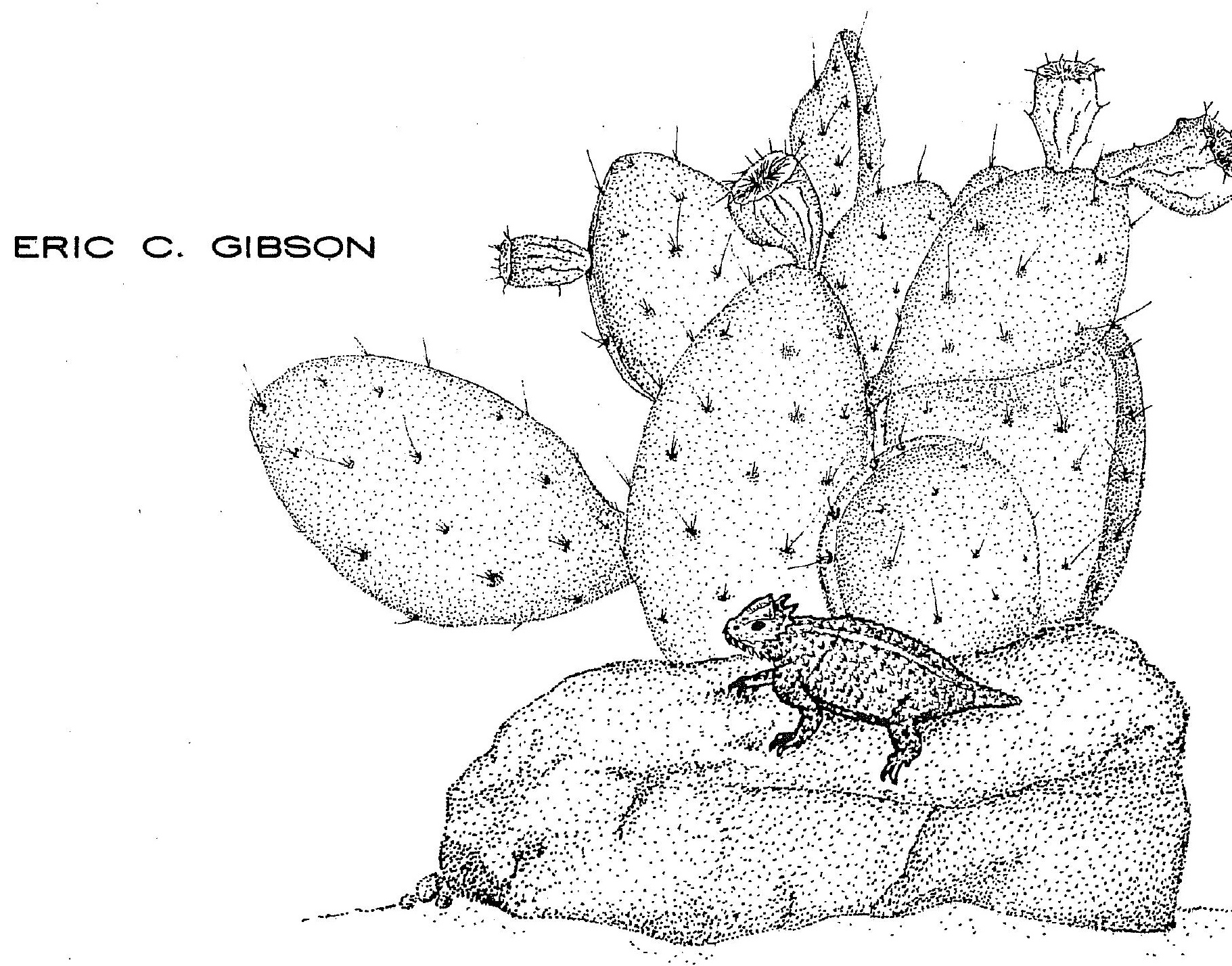

Center for Archaeological Research

The University of Texas at Son Antonio

Archaeological Survey Report No. 102

1981 



\title{
UTSA = Center for Archaeological Research
}

\section{THE SANTONINO PROJECT}

AN ARCHAEOLOGICAL RECONNAISSANCE

FOR UREX, INC., SOUTHEASTERN WEBB COUNTY, TEXAS

\author{
Eric C. Gibson
}

Center for Archaeological Research

The University of Texas at San Antonio

Archaeological Survey Report, No. 102 


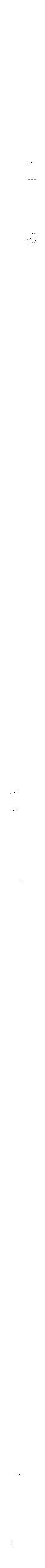




\section{ABSTRACT}

In October 1980, archaeologists from the Center for Archaeological Research, The University of Texas at San Antonio, under contract to Fisher, Harden and Fisher, Inc., completed an archaeological survey of a proposed locality for solution uranium mining wells in southeastern Webb County, Texas. This survey produced evidence of Middle Archaic to Late Archaic prehistoric sites in the area. Twelve archaeological sites were documented. Five of these sites, located in the proposed mining area, were totally collected and mapped. The other seven sites outside of the proposed mining area were mapped and only those sites with cultural/historical significance were collected. No further work is necessary to protect those sites in the area of the proposed uranium mining. 

TABLE OF CONTENTS

Page

Abstract. .................... . . $i$

List of figures................... iv

List of Tables.................... iv

Acknowledgments .................... v

Introduction. . . . . . . . . . . . . . . . . 1

Environmental Setting . . . . . . . . . . . . . 3

The Chronology of Prehistoric Occupation. . . . . . . . . . . 4

Previous Archaeological Research in Webb County . . . . . . . . . 10

The Santonino Project Investigations. . . . . . . . . . . . 11

Methodology. .................. 11

Artifact Terminology . . . . . . . . . . . . . . . 11

Site Investigations. . . . . . . . . . . . . . 14

Summary and Conclusions ......... . . . . . . . . . 24

Chronology ................... 26 26

Regional Comparisons............... . 26 26

Applicability of Recent Models of Prehistoric Hunter-Gatherer

Adaptive Systems to Santonino Data . . . . . . . . . . . 27

References Cited. . . . . . . . . . . . . . . . 32 


\section{LIST OF FIGURES}

Figure

Page

1. Santonino Project Area Indicating Locations of Archaeological Sites ............. 2

2. Selected Artifacts from Santonino Project Sites. ....... 13

3. Selected Artifacts from Santonino Project Sites. . . . . . 15

\section{LIST OF TABLES}

Table

1. General Chronology for Southern Texas. . . . . . . . 4

2. An Alternative General Chronology of the Archaic Period. . . . . 6

3. Summary of the Archaic Period Paleoenvironmental Data from South and East-Central Texas ............. 8

4. Probable Cultural Association of Formal Artifact Types Recovered from 47 WB 71 . . . . . . . . . . . . . 19

5. Santonino Project Site Types, Their Intensity of Occupation, Diagnostic Artifacts and Associated Cultural/Historical Periods. . 25

6. Components of Binford's Forager Model for Hunter-Gatherers . . . 29

7. Components of Binford's Collector Model for Hunter-Gatherers . . . 29

8. Cultural System Variety in Santonino Project Area. . . . . . . 30 


\section{ACKNOWLEDGMENTS}

In large part the success of this project is due to the adroit assistance of Paul D. Lukowski, staff archaeologist of the Center for Archaeological Research. Paul provided valuable advice during the field reconnaissance. I also thank Kathy Bareiss for her illustrations of the artifacts in Figures 2 and 3 and for the cover design.

Thanks go to Jack Eaton, Associate Director of the Center for Archaeological Research, and Dr. Thomas R. Hester, Center Director, for their encouragement and counsel on project operations.

The Santonino Project is being developed by Urex, Inc. We are grateful for their financial support of the investigations reported here.

I would especially like to thank Carla Fisher and Larry McGonagle of Fisher, Harden, and Fisher, Inc., for their help in obtaining land access to the Santonino Project area. Ms. Fisher and Mr. McGonagle also provided us with copies of their project maps.

This manuscript was typed by Carmel Y. Graham and edited by Sharon G. Quirk. 



\section{INTRODUCTION}

During October 22-24, 1980, archaeologists from the Center for Archaeological Research (CAR), The University of Texas at San Antonio (UTSA) conducted an archaeological reconnaissance 7.5 miles northwest of Bruni in southeastern Webb County, Texas. The field work was done for Urex, Inc., under contract with Fisher, Harden and Fisher (consultants in solution mining, Beeville, Texas). The Santonino Project area is the locality for a proposed series of solution uranium mining wells and a processing plant, with such associated facilities as an office, laboratory, waste holding pond, workshop, and parking area. An intensive archaeological reconnaissance of 290.6 acres was conducted in the proposed mining activity and plant location areas (see Fig. 1). Additional predictively selected reconnaissances were conducted in areas where environmental conditions indicated archaeological sites might potentially be located (see Fig. 1). Field work was accomplished by Eric C. Gibson and Paul D. Lukowski, CAR archaeologists. Laboratory analysis, background research, and interpretation of the results were completed by Gibson. Dr. Thomas R. Hester, Director of CAR and Jack D. Eaton, Associate Director, provided overall supervision of the project.

The investigations described in this report were carried out in order to assess and document the archaeological sites in the project area because they may soon be altered by the proposed mining and plant construction activities (Fig. 1). A total of 12 prehistoric archaeological sites were discovered during field work. Five of these sites, located in the proposed mining area were totally collected and mapped (Fig. 1). The other seven sites outside of the proposed mining area were mapped and only those artifacts with cultural/historical significance were collected. The horizontal distribution of lithic materials constituted the criterion for delimiting overal1 site area boundaries.

Field reconnaissance methodology was derived from the guidelines presented in Field Methods in Archaeology (Hester, Heizer and Graham 1975). The study of these archaeological sites was aimed towards: (1) describing their spatial and temporal distribution and possible relationships; (2) recovering artifacts that indicate prehistoric activities, site function, and chronological placement; and (3) ascertaining the applicability of two recent models of prehistoric hunter-gatherer adaptive systems (Jochim 1976; Binford 1980) to south Texas prehistory.

A11 information was recorded on standard site report forms presently used by the Center for Archaeological Research. Black and white 35-mm photographs were taken of each site and the general area. A11 collected artifacts were placed in paper bags and labeled according to site number, date, and collector's name. The interpretations presented in this report are based on examination of the sites, the artifacts observed and collected and data recorded in photographs, site forms and field notes. 
This page has been

redacted because it

contains restricted

information. 


\section{ENVIRONMENTAL SETTING}

Southeastern Webb County lies in the South Texas Plains physiographic region (Fenneman 1931). Gently rolling hills dissected by the erosional gulleys (or draws) of ephemeral streams, characterize the local area. Elevations range from approximately 830 to over 900 feet above mean sea level.

Surface geology is typified by outcrops of siliceous gravels along some slopes. The soils in the project area are moderately permeable, gravelly, grayish or reddish tan, sandy loams.

Webb County, like most of south Texas and northeastern Mexico, is included within the Tamaulipan Biotic Province (Blair 1950). Generally, the climate has high temperatures and low rainfal1; summers are hot and humid with maximum rainfal1 occurring in May and September. Winters are dry and mild and the lowest rainfall occurs from November through March. Annual rainfall is approximate1y 20-22 inches (Hester 1980:33-34).

In the Santonino Project vicinity vegetation is abundant and primarily consists of creosote brush, mesquite, huisache, prickly pear, short grasses, and thorny brush. In recent years the surface area has been altered considerably by human activity, particularly by ranching and its associated activities (1ivestock grazing and rootplowing).

Within the Tamaulipan Biotic Province, Blair (1950) identified 61 species of mammals, 36 species of snakes, 19 lizard species and a few species of turtles and frogs. Fauna recognized in the project area during our field work included white-tailed deer, coyote, various owls, hawks, turkey vultures, doves, horned toads, various lizards and one western diamond back rattlesnake.

Apparent7y, the last 150 years have greatly altered the environment of the south Texas region, as Hester has observed (1980:34).

The widespread mesquite forests which choke the area today are a comparatively recent phenomenon, reflecting changes caused by ranching and farming since the nineteenth century. The spread of mesquite and thorn brush is probably the result of several factors. These include the commercial livestock industry (which led to overgrazing and the increased dispersal of mesquite seeds), short-term climatic changes, and the suppression of grass fires.

Early Spanish records describe a region of gently rolling grassy hills with mesquite occurring primarily in upland gravel areas and in scattered thickets along stream courses (Ingl is 1964).

In the last few centuries, before European contact, there was more surface water available in south Texas than at present. Historic records show that the major rivers, creeks, and many smaller tributaries flowed year round. Water was carried in many of the larger creeks as recently as the late 1930s (Hester 1980:34). Overgrazing destroyed the watershed as muddy run-offs clogged the springs which fed the creeks. Concomittantly, the water table 
was a7so lowered in many areas by deep-well irrigation farming. All of these cultural factors transformed the streams into dry beds that today carry water only after heavy rains (ibid.).

\section{THE CHRONOLOGY OF PREHISTORIC OCCUPATION}

The following summary describes current concepts of the succession of cultures and their characteristics in south Texas. In this discussion all dates for cultural-historical periods are considered approximate. The term "culturalhistorical period" as used in this report indicates a range of behavioral and cultural activities and their observed traits within a broad geographic and temporal setting (Gibson 1980:3).

Recent excavations have shown that North America has been inhabited for at least 15,000 years (Adovasio et al. 1978, 1980). During this long time span, basic patterns of life and material cultural changed dramatically. These changes may be divided into five sequential periods that outline the development of prehistoric cultures for most of south and west Texas (Hester 1980; see also Table 1).

TABLE 1. GENERAL CHRONOLOGY FOR SOUTHERN TEXAS

\author{
Cultural-Historical Period \\ Historic \\ Late Prehistoric \\ Archaic \\ Pre-Archaic \\ Paleo-Indian
}

\author{
Dates \\ After A.D. 1530 \\ A.D. $1000-1530$ \\ 3500 B.C.-A.D. 1000 \\ $6000-3500$ B.C. \\ $13,000-6000$ B.C.
}

Paleo-Indian (13,000 to 6000 B.C.)

Most archaeologists use the term Paleo-Indian when referring to the earliest human inhabitants of North America. Other terms such as Early Man or PaleoAmerican have equivalent meaning but are used less frequently (Jennings 1974). The Paleo-Indian period is the least understood cultural manifestation in North America. Some archaeological data suggest that humans entered North America from eastern Asia as early as 30,000 years ago (Krieger 1964; Gagliano 1967). However, these data remain controversial. Conclusive evidence places the initial peopling of North America within the terminal stages of the Wisconsin Glaciation, ca. 13,000 to 11,000 B.C. (Jennings 1974; Adovasio et al. $1978,1980)$. At present though, the majority of the reliable dates for PaleoIndian occupation of North America fal1 between 10,500 B.C. and 6000 B.C. (Hester 1980). 
During the greatest advance of the Wisconsin Glaciation, paleoenvironmental data suggest the land in southern Texas was primarily piñon pine parkland (01dfield and Schoenwetter 1975). Two major cultural traditions have been recognized by Hester (1976:5) in Texas and northeastern Mexico at ca. 8000 to 9000 B.C. These traditions may be indicators of cultural adjustments to local environments and subsistence resources. Hester (ibid.) has observed that:

The most visible of these is the Plains-related Tradition. In this I would group all of the Clovis and Folsom sites known thus far in the state.

Hester (ibid.:6) also observes that the Sma11 Projectile Point Tradition emerges from northeastern Mexico during this interval (ca. 8000-9000 B.C.). Based on the work of Epstein (1975), evidence from the La Calsada site in Nuevo Leon, indicates this tradition began as early as 8600 B.C. (ibid.).

During this early period in Texas and the western plains, megafauna such as giant bison, mammoth, camel and horse were hunted. In North American prehistory, focus has been placed on the "Big Game Hunters" of the Plains-related Tradition. However, many sites (Meadowcroft, Lindenmeir, Lubbock Lake, Blackwater Draw) show evidence that small game and wild plants were also important food resources (Jennings 1974; Adovasio et al. 1980). Plains-related Paleo-Indian occupation of south Texas is indicated by surface finds of Clovis, Folsom, Plainview, Golondrina, and Meserve projectile points throughout the area (Hester 1976, 1980).

The Amistad Reservoir region near Del Rio is in a transitional zone between Southern and Trans-Pecos Texas. Sites in this area have produced subsurface evidence of Paleo-Indian occupations. Bone Bed 2 at Bonfire Shelter contained Folsom and Plainview projectile points in direct association with extinct bison (Dibble and Lorrain 1967). The lowest level of the Devil's Mouth site contained Lerma, Angostura, Plainview and Golondrina projectile points (Johnson 1964). Golondrina points dated at 2000 B.C., occurred in the lowest cultural stratum at Baker Cave (Hester 1979).

In summary, these lanceolate projectile points (fluted and non-fluted) of various sizes and fine workmanship are diagnostic artifacts characteristic of PaleoIndian assemblages. Other chipped stone artifacts, such as steeply-retouched end scrapers, are often found at Paleo-Indian sites. Groups of this period probably lived in smal1 nomadic bands and subsisted by hunting large and smal1 game and by gathering edible wild plants. In general this period is not well understood and throughout North America there is, particularly, a need for additional evidence of subsistence and settlement patterns as they pertain to local adaptative and more stratified, well-dated sites.

Pre-Archaic (6000 to 3500 B.C.)

The Pre-Archaic period was first described by Sollberger and Hester (1972). After further work it has been identified as a legitimate cultural historical period across central and south-central Texas (Hester (1976, 1980). Alternatively, other 
researchers have questioned the utility of this term "Pre-Archaic" and prefer to divide the Archaic into three sub-periods, Early, Middle, and Late, with the following general chronology (Story $n . d .: 10$; see also Table 2):

TABLE 2. AN ALTERNATIVE GENERAL CHRONOLOGY OF THE ARCHAIC PERIOD.

Sub-Periods

Early Archaic (or Pre-Archaic)

Middle Archaic

Late Archaic
Dates

6000 to $3500 / 300$ B.C. $3500 / 3000$ to 1000 B.C. 1000 B.C. to 200 B.C. (in some regions, to as late as A.D. 1200 in other regions)

The establishment of a well-defined cultural historical sequence is a basic requirement for archaeological research. As evidenced by the current disagreement over which general chronology is most useful, the transitional period between Paleo-Indian and Archaic occupations of Texas is poorly understood. For that matter, the Archaic period itself is weakly defined (ibid.). Therefore, the Pre-Archaic and Archaic periods must be discussed in provisional terms until archaeological research progresses.

Paleoenvironmental data indicate the piñon pine parkland of Texas was gradually replaced by a grassland savanna early in this period (Bryant 1969; Bryant and Shafer 1977). Furthermore, the time span between ca. 5000 to 3000 B.C. may have been a period of prolonged aridity (Story n.d.:12). This increasingly semiarid climate probably diminished the amount of available ground water.

During the post-Pleistocene, climatic warming trends occurred throughout most of North America. From region to region climatic conditions and biotic provinces varied considerably. Throughout Texas and northeastern Mexico, cultural groups of the Pre-Archaic adjusted to and reflected this environmental variability, as can be seen in the diversified tool assemblages from various areas. As Pleistocene megafauna became extinct, more animals such as bison, deer, rabbit, squirrel, and other smal1 game were hunted (Marmaduke 1978). Due to arid conditions such game may have frequently been scarce in the region.

During this interval, techniques and tools for hunting and plant processing gradually became more specialized. Additionally, Pre-Archaic population densities were probably low throughout Texas (Soliberger and Hester 1972; Weir 1976; Story n.d.). The Pre-Archaic settlement pattern has been summarized as follows (Story n.d.:13): 
The sites are characteristically small, widely distributed, and non-specialized. They are often surface or slightly buried scatters of lithic tools and debitage on knolls and fossil floodplains, many times mixed with later materials. Less common are components deeply buried in alluvial terrace deposits. When deeply buried components are found, they usually underlie larger Middle and Late Archaic occupations.

To summarize, the Pre-Archaic period was more arid and warmer than the PaleoIndian period. Tools and food gathering techniques became more diverse. Typical Pre-Archaic projectile points are triangular, corner-notched, and stemmed varieties. Significant Pre-Archaic sites in southern and western Texas are Devil's Mouth, Rockshelter and Baker Cave (Hester 1980:147-148). However, throughout the region population densities were probably quite low.

Archaic (3500 B.C. to A.D. 1000)

Paleoenvironmental data from south and east-central Texas indicate that drying conditions that began in the Pre-Archaic continued into the Archaic period (see Table 3). Though comparable information is lacking for extreme south Texas (Webb County) these data show that climatic fluctuation may have been more frequent in some regions and less so in others. Research conducted in central Texas has suggested that the driest interval in that area was from 3000 to 2000 B.C. (Gunn and Weir 1976:32). These climatic fluctuations probably influenced but did not determine prehistoric human patterns of adaptation in these regions (Story n.d.).

In terms of a general overview, Archaic sites are more varied and numerous than those of the Pre-Archaic and are probably indicators of an increase in population (ibid.). Many archaeologists have discerned this increase in population to have been a sudden occurrence (Sollberger and Hester 1972:338; Weir 1976:124; Gunn and Weir 1976:32). This possibility is tentatively supported by the Santonino project data and is described in the discussion chapter of this report.

Sollberger and Hester (1972) have also suggested that the arid conditions were ameliorated in Texas at this time and therefore the habitat became more productive. Additionally, Hester (1978) has pointed out that in south Texas where food resources were (and are) irregularly spaced, short term climatic fluctuations would have an adverse impact on the prehistoric inhabitants. 
TABLE 3. SUMMARY OF ARCHAIC PERIOD PALEOENVIRONMENTAL DATA FROM SOUTH AND EAST-CENTRAL TEXAS.

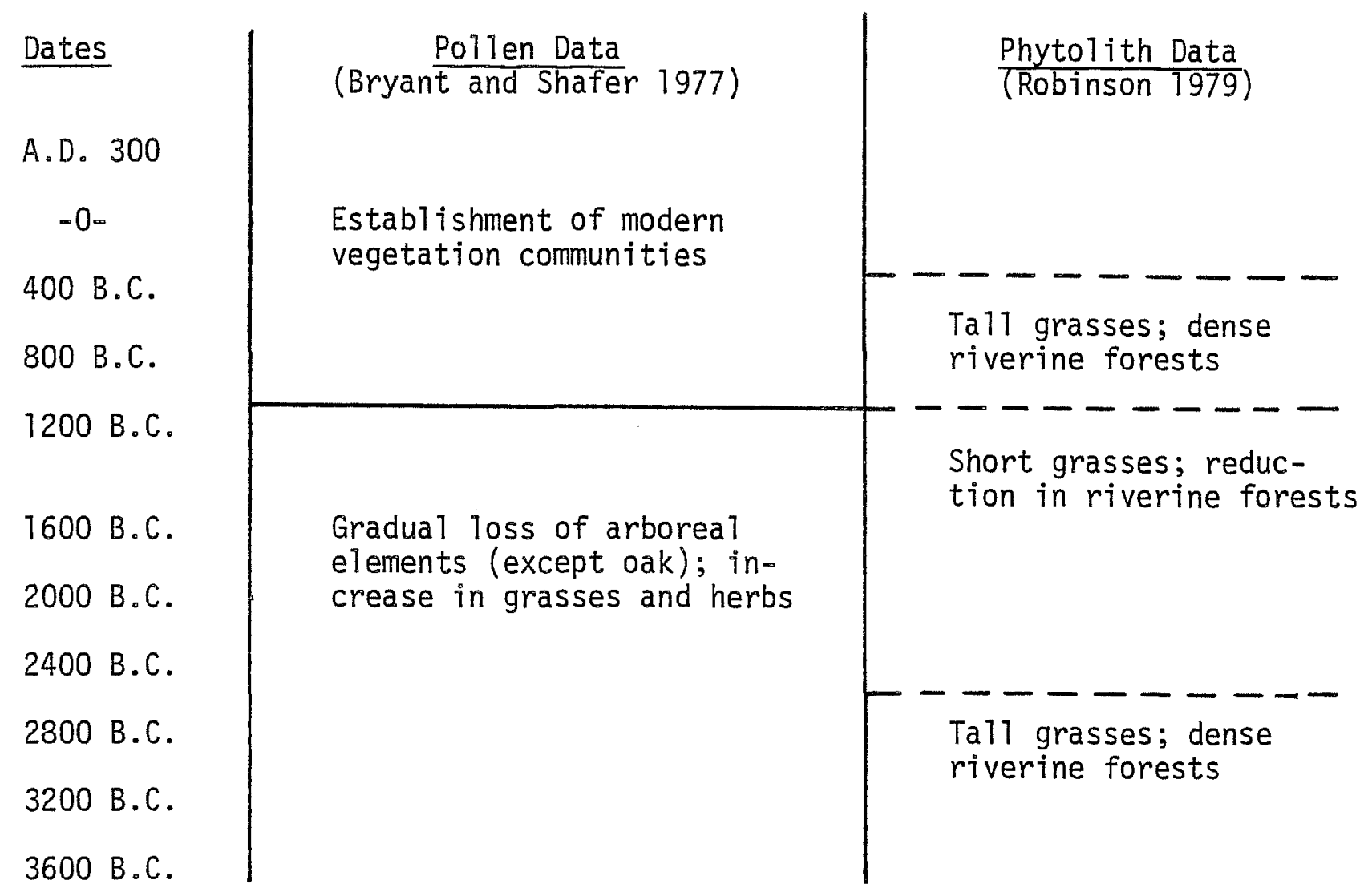

Southern Texas was predominantly characterized by a savanna (or prairie) vegetational pattern during the Archaic period. But the region may have been as ecological7y diverse then, as it is now. At present, high densities of food resources cluster along the major river systems (Rio Grande, Nueces, Frio and San Antonio) and the coast (Hester 1978).

During the Archaic period seed-bearing plants and succulents (such as prickly pear) became increasingly important food resources to the local inhabitants of south Texas. As in the Pre-Archaic, hunting continued to be focused on deer, bison, and small game.

Evidence of bison hunting in the Amistad region is present at Bonfire Shelter and is dated to approximately 3200 B.C. (Dibble and Lorrain 1967). Evidence also suggests that bison were not always available. A study of Dillehay (1974) indicates that bison were absent during two different periods, from approximately 5800 to 3200 B.C. and from 1000 B.C. to A.D. 200. Dillehay also suggests that warmer climatic fluctuations may have caused these hiatuses.

The regional cultural diversification that began in the Pre-Archaic became more pronounced during the Archaic period (Story n.d.). However, Kelley (1959), writing at a high level of generalization, proposed the "Monte Aspect" 
as part of the "Balcones Phase" and within this construct he subsumed most of the Texas Archaic. Kelley contended that the Texas Archaic linked the Eastern Midcontinent Archaic Tradition and the Desert Archaic of western North America. Kelley's viewpoint has recently been supported by Jennings (1974:32). But the idea of a homogenous, instead of a regional1y diverse, Texas Archaic has been rendered untenable (Hester 1975, 1976).

The Archaic period in south Texas is characterized by such lithic artifacts as percussion flaked, triangular, leaf-shaped, and stemmed projectile points, various manos, metates, and other grinding stones, unifacial and bifacial choppers, gouges, various large scrapers, drills, and utilized flakes. "Perishable" artifacts such as baskets, mats, nets, fur and leather cloth, sandals, cordage, wooden darts, atlatis, and clubs have been reported from Archaic components in southwest Texas rockshelters (Kelley 1959:281).

The problems discussed previously in the Pre-Archaic section are also problems that characterize the present state of Archaic period research in south Texas.

Further research is necessary, particularly in studies of refined chronologies, paleoenvironmental reconstruction, and synchronic and diachronic relationships between interregional adaptive strategies.

Late Prehistoric Period (A.D. 1000 to A.D. 1530)

The Archaic and the Late Prehistoric period are separated by a set of technological innovations, most notable the introduction of the bow and arrow. Sma11, very light, and thin pressure-flaked projectile points of various types (Perdiz, Scallorn) are diagnostic artifacts of the Late Prehistoric period.

The bow and arrow diffused into some regions of Texas earlier than in others and thus the beginning of the Late Prehistoric varies across the state. Other indicators of this period are new kinds of lithic tools, (blade technology, end scrapers, beveled knives) pottery manufacture and agriculture in some areas.

Historic Period (A.D. 1530 to A.D. 1900)

Cabeza de Vaca's travels through southern and western Texas during the 1520 s and 1530s is the first documented contact between Spanish explorers and the aboriginal inhabitants. However, the Europeans had minimal cultural impact on the natives of south Texas until the arrival of the Spanish missionaries during the late 1600s (Hester 1980:160).

Southern Texas throughout the Historic period was the domain of possibly hundreds of bands of Indians who spoke Coahuilteco ("Coahuiltecan") and other poorly-known languages. Hester $(1980: 40)$ has described the generalized lifeways of these bands as: 
The Coahuilteco and other hunting and gathering Indians in southern Texas lived in small groups, each with a distinctive name and territory utilized for the hunting, plant food gathering, and fishing necessary to obtain subsistence. They moved throughout their territories, sometimes overlapping into the territories of other groups, in a seminomadic fashion. More detailed population and territorial estimates are difficult, as many groups were often found in widely separated areas during the seventeenth and eighteenth centuries. Villages were established at favored locations near rivers or creeks, occupied for a short time, and then the group would move on.

As the missions were built and more Spaniards settled south Texas the cultural impact on the region's aboriginal population resulted in their either being missionized, displaced to remote areas, assimilated into Spanish Mexican groups or killed by introduced diseases from the Europeans (Montgomery 1978:22).

\section{PREVIOUS ARCHAEOLOGICAL RESEARCH IN WEBB COUNTY}

In this section a brief review is provided of archaeological research in webb County. A more detailed summary of archaeological research in south Texas is available in Hester (1980).

Few archaeological projects have been conducted in Webb County. Many other south Texas counties (Hidalgo, Willacy, Zavala, Starr) are much better known (Mallouf et al. 1977; Hester 1978; Montgomery 1978). In northern Webb County, Shiner's (1969) research is the earliest reported work. Most of the archaeological work prior to 1977 was carried out by amateurs (Saunders 1976; Saunders and Saunders 1978; Beasley 1978). In recent years, most of the work reported from Webb County has been the result of historic and prehistoric cultural resource management projects conducted by the Center for Archaeological Research (The University of Texas at San Antonio) (Ha11 1973; Fox and Uecker 1977; Ivey et al. 1977; Medl in 1977a, 1977b; Fox 1978a, 1978b, 1979; Kel1y 1979).

The most extensive research contribution to the archaeology of Webb County is that of Nunley (1971), who investigated the Archaic of the area. He examined lithic collections from over 50 sites in the region from Falcon Dam to Laredo, Texas. A result of his analysis was the identification of five hypothetical sociocultural units. Each unit, according to Nunley, was territorially limited and had a distinctive sociocultural pattern. He found two lithic technologies to be characteristic of these units: (1) a technology that consists of the reduction of stream worn pebbles into bifacial tools; and (2) a technology that consists of the modification of flakes into tools. Nunley (ibid.) observed that both technologies were present in all five hypothetical sociocultural units, but in varying degrees. Two of Nunley's units are considered in the Summary and Conclusions of this report. 
THE SANTONINO PROJECT INVESTIGATIONS

The investigations involving the Santonino Project area are presented in three sections. First, the field research methods are discussed. Second, artifact categories and terms are defined (derived from Gibson 1980:9). Third, the sites and their associated artifacts are described.

Methodology

After familiarizing ourselves with the project area, boundaries, and topography we located the intended southwest corner of the plant and commenced surface reconnoitering of the 290.6 acres of proposed mining area.

Several maps of test walls and core sample holes were provided by Fisher, Harden, and Fisher, Inc., and these were valuable aids for checking our compass bearings and transects.

The reconnaissance transects were conducted on foot and were guided with the aid of a Brunton compass. Both persons held to the compass bearing and stayed parallel to each other at a distance of 32 meters. When a site was encountered, each person marked where they left their transects with a stake or flagging tape, then proceeded to document, photograph the sites, and collect artifacts. Upon completion of a transect the reconnaissance team would move 32 meters away and commence the next transect. These procedures were repeated until the intensive reconnaissance of the 290.6 acres of proposed mining activity and plant location area was completed.

Upon completion of the intensive reconnaissance, we examined our maps and forms to make sure the data were recorded correctly. We studied the distribution of the sites in the proposed mining area and observed that all five of the sites had one factor in common: they were located on small rises (or hilltops) on the south side of dry stream beds (or draws). Isolated artifacts were found in and around the dry stream beds, but all of the archaeological sites were distributed on low rises or hilltops. We derived a basic predictive model of site distributions in the Santonino region based on this observed pattern, and targeted a11 of the low rises and hilltops south of draws in the remainder of the project area, as zones for further surface examination. In the 10 target zones we selected, seven archaeological sites were found, documented, and collected of diagnostic artifacts. We concluded that our predictive model of site distribution patterns was supported.

Artifact Terminology

Bifaces: These are tools which have had flake removals from both the dorsal and ventral surfaces and also along at least one edge of the implement (see Fig. 3,d). In this report bifaces are separated into thin or thick categories. In some cases thin bifaces were probably used as cutting tools or knives and thick bifaces may have had other uses (such as chopping and/or cutting). They may also have been "preforms" which are bifaces that may have been intended for further modification into knives or projectile points. 
Cones: Cores are pieces of siliceous stone or other raw materials which have at least one surface from which flakes have been removed.

Core Tools: These exhibit attributes of cores, but additionally show marginal retouch, modification, or wear (observable alteration caused by use) along portions of the edge (see Fig. $2, a$ ).

Cortex: A stone's weathered surface.

Flake: A piece of stone that has been removed from a core through the introduction of force into the core. In this report, flakes are considered only to be the result of human flintworking activities. Diagnostic attributes of a flake are: a striking platform, ripples, fissures and a bulb of percussion.

Flakes with Edge Modification: These are flakes which show modification on one or more edges. However, whether the edge modification resulted from cultural or natural processes is indeterminate on these specimens.

Hammerstones: These are usually round or rounded nodules of stone which show evidence of battering (smal1 craters, abrasions, etc.) on one or more ends.

Interior Flake: A flake lacking cortex, usually the most common flake form found at a site. Interior flakes are flintworking debitage produced from a core, another flake, or a tool which has had all cortex detached from previous flake removals.

Primary Cortex Flake: A flake characterized by a cortex dorsal surface.

Projectile Point: Usually a bifacial tool used on the distal end of a projectile such as an arrow, atlatl dart, or spear, commonly called an "arrowhead" (Figs. 2,b;2,d;2,e; 2,h;3,a-c;3,e;3,f;3,h).

Scrapers: These formalized tools show either unifacial or bifacial modification. They may also have steep edge angles (Figs. $2, f ; 2, g$ ). Wear patterns are often common along edges in the form of damage and/or polish.

Secondary Cortex Flake: A flake characterized by some cortex remaining on the dorsal surface. These flakes are indicative of flintworking activities. 

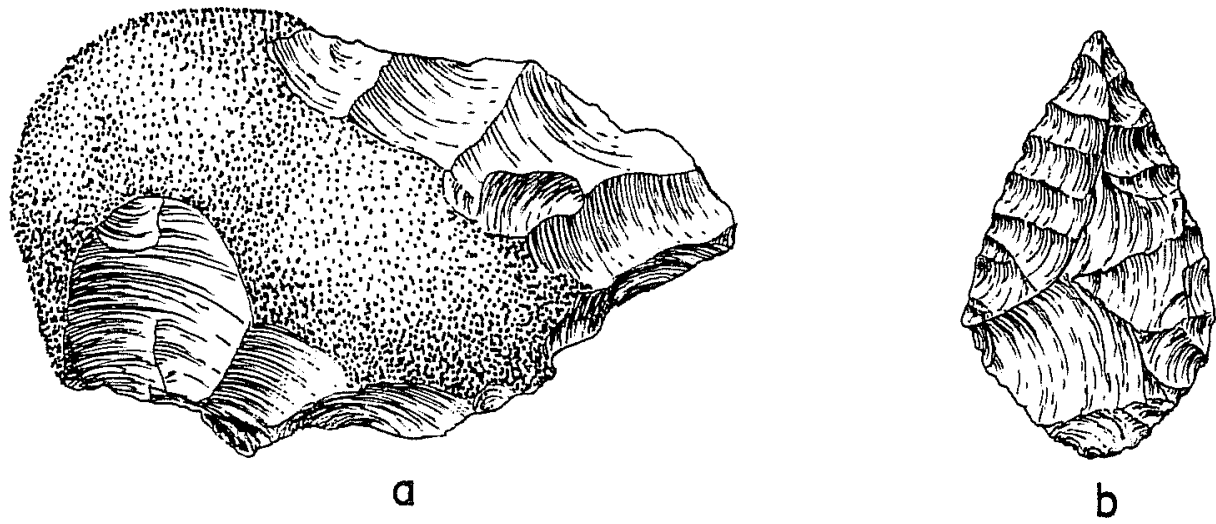

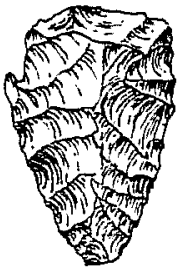

C

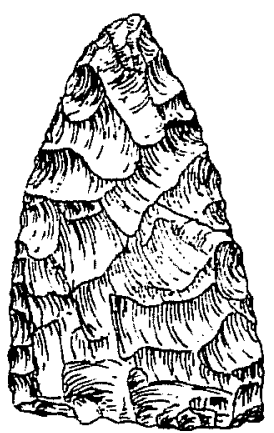

d

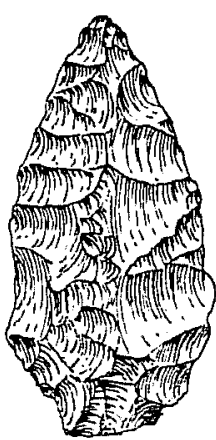

e

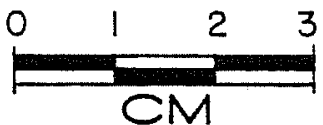

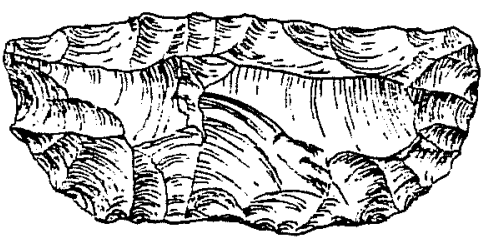

$f$

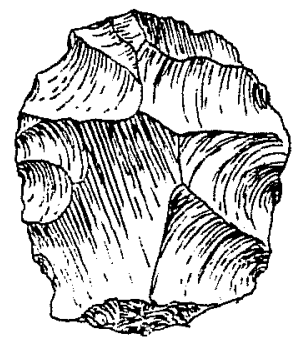

g

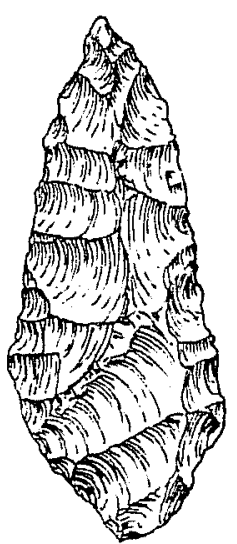

h

Figure 2. Selected Artifacts from Santonino Project Sites. a, core tool (41 WB 69); b, Desmuke projectile point (41 WB 69); c, 01mos biface (41 WB 71); d, Tortugas projectile point (41 WB 71); e, Desmuke projectile point (41 WB 71); $f$, Nueces scraper (41 WB 71); g, end scraper (41 WB 71); $h$, Desmuke projectile point (41 WB 71 ). 
Unifaces: Unifaces are tools which have been modified on only one surface and one edge. Edge modification was the result of intentional retouch and use. The uniface category applies to any non-formalized unifacially worked tool.

\section{Site Investigations}

In this report, sites are considered to be the location of one or more prehistoric activity areas. These are spatially restricted areas where a specific task or related tasks occurred (hunting, camping, cooking, tool manufacturing and/or replacement, hide-working, etc.). Sites and their associated activity areas are generally characterized by waste products, a scatter of tools and/or raw materials (Flannery 1976:34). Twelve prehistoric sites were located and documented during the project. The locations of these sites are shown in Figure 1.

SITE: 41 WB 67

Environmental Location: This site is located on a low rise south of a dry stream bed. The topography of the area is characterized by a series of gentle slopes dissected by dry stream beds. A windmi 11 and pond is located approximately 150 meters southeast of the site. The soil in the site area is a reddish brown sandy loam. Thorny brush and prickly pear occur in the site area.

Artifacts Recovered: One hammerstone, 5 interior flakes, 6 secondary cortex flakes, 2 primary cortex flakes.

Description: This site appears to have been a flintworking activity location that was perhaps briefly occupied. It is roughly ovoid in shape and is approximately 15 meters long (east to west), and 7 meters wide (north to south). No burned or fire-cracked rock was observed in the site vicinity.

Probable Cultural Associations: Unknown.

Condition: Severely disturbed by root plowing within the last five years.

Recommendations: The reconnaissance team collected all of the artifacts observed on the site surface. There is no evidence of buried, undisturbed deposits. No further work is recommended. 

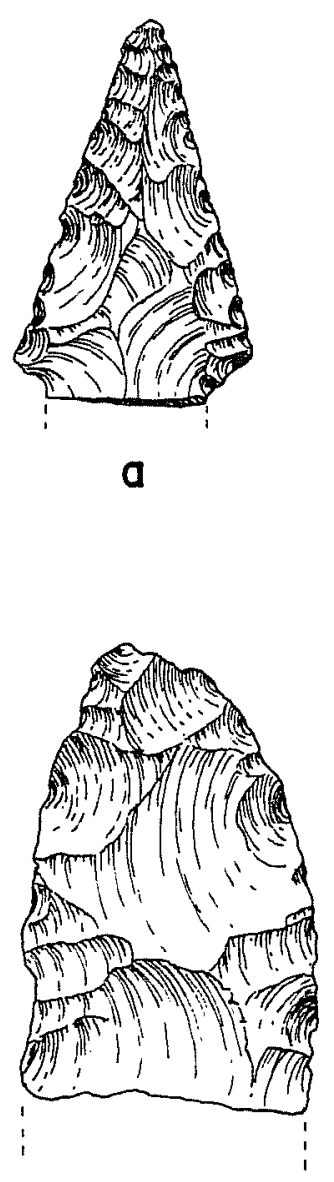

d

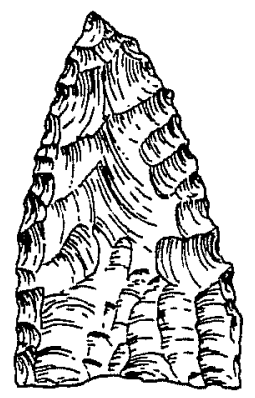

b

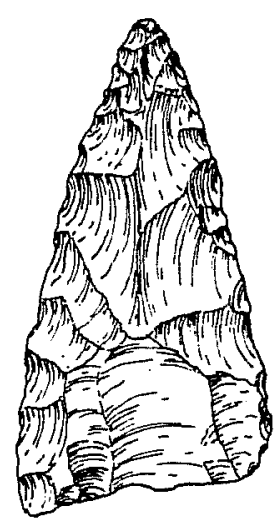

e

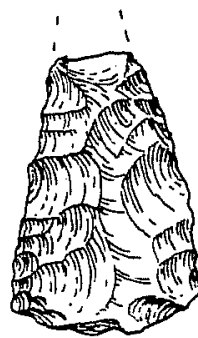

C

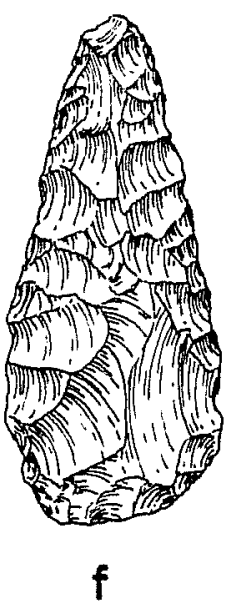

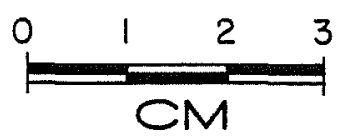
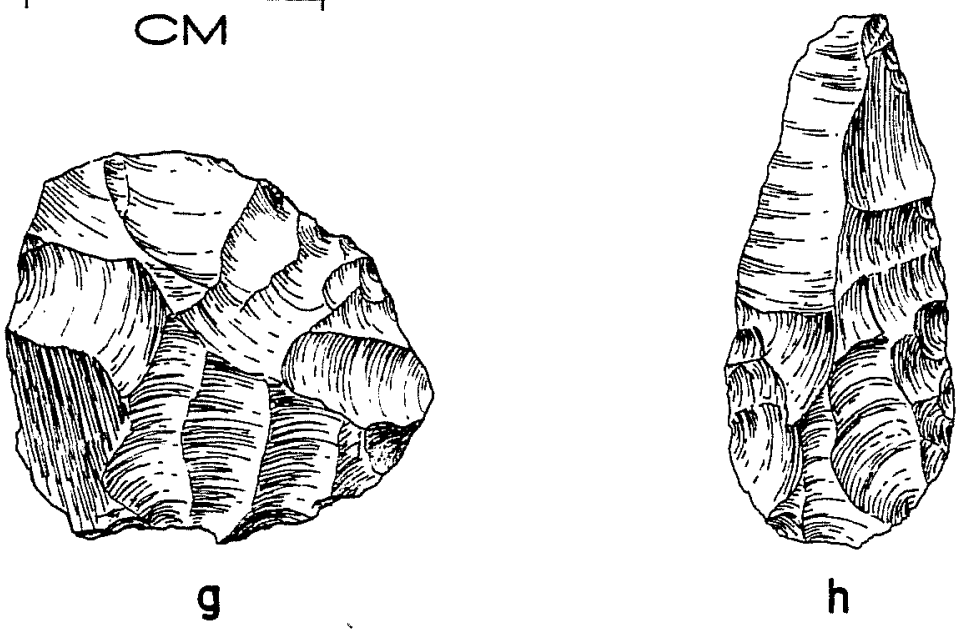

K.L.B. 1960

Figure 3. Selected Artifacts from Santonino Project Sites. a, stemmed projectile point with broken base (41 WB. 73); b, Tortugas projectile point (41 WB 74); c, triangular projectile point (41 WB 74); d, thin biface, broken (41 WB 74); e, Tortugas projectile point (41 WB 74); $f$, Abasolo projectile point (41 WB 74); g, thin biface (41 WB 76); h, Abasolo projectile point (47 WB 76 ). 
Additional Remarks: Approximately 150 meters northwest of 41 WB 67 an isolated thick biface was found on the slope of a low rise. Possibly this biface also represents a very brief prehistoric activity (perhaps cutting or chopping plants or butchering animals). This biface was not collected by the reconnaissance team.

SITE: 41 WB 68

Environmental Location: This site is located on a gentle slope, south and east of a dry creek bed. The creek bed is approximately 700 meters away. The soil in the site area is a grayish brown, sandy loam. Thorny brush, prickly pear, creosote brush, short grasses and low growths of mesquite occur in the site vicinity.

Artifacts Recovered: Three flakes with edge modification, 11 interior flakes, T scraper, 3 secondary cortex flakes, 3 utilized flakes.

Description: Judging from the artifacts 1 isted above, particularly the presence of the scraper and utilized flakes, the low amount of artifacts and the presence of fire burned and cracked rock in the site vicinity; this site was probably a temporary field camp. It is roughly circular and measures 15 by 15 meters.

Probable Cultural Associations: Unknown.

Condition: Severely disturbed by root plowing within the last 5 years.

Recommendations: The reconnaissance team collected all of the artifacts observed in the site area. There is no evidence of buried, undisturbed cultural deposits. No further work is recommended.

SITE: 41 WB 69

Environmental Location: This site is located on the south slope of a low rise, situated between two dry creek beds. A windmi11 and pond are 10cated approximately 50 meters southeast of this site. The soil in the site area is a grayish brown, sandy loam. The predominant vegetation in the site vicinity is mesquite and thorny brush.

Artifacts Recovered: One core tool/hammerstone (Fig. 2,a), 8 interior flakes, 2 primary cortex flakes, 2 projectile points (Fig. 2,b), 3 secondary cortex flakes, 1 uniface. 
Description: The artifacts recovered, the other low density artifacts (various fTakes, etc.) observed but not collected, and the presence of fire-cracked and/or burned rock suggest that this site may have been a field camp, where various hunting related activities took place. It is irregularly shaped and covers an area approximately $40 \mathrm{~m}^{2}$.

Probable Cultural Associations: The two projectile points recovered are variants of the Desmuke type (Fig. 2,b) which has Archaic cultural affiliations (Suhm and Jelks 1962:181). Desmuke projectile points are also considered to be probably related to both Abasolo and Catán projectile points (ibid.). On the distribution of Desmuke projectile points Suhm and Jelks (1962) observe:

Apparently (Desmuke points are) most frequent along the middle parts of the Frio and Nueces River valleys, decreasing southward toward the lower Rio Grande, and toward the coast in Nueces and Kleberg Counties.

Thus, (according to Suhm and Jelks) the Desmuke points found in the Santonino Project area are slightly south of the region where they are most common. However, Nunley $(1971: 178)$ says they are concentrated in the vicinity of Laredo and southern Webb county.

Condition: Site has been moderately disturbed by root plowing within the last 10-15 years.

Recommendations: Since 41 WB 69 is located outside of the proposed mining area and there are no apparent buried, undisturbed cultural deposits; no further work is recommended.

Additional Remarks: The Desmuke points found at 41 WB 69 may have a Middle Archaic, 3500 B.C. to 1000 B.C. (Suhm and Jelks 1962:181) association. However, they are not well dated.

\section{SITE: 41 WB 70}

Environmental Location: This site is situated on the south slope of a low ridge approximately 150 meters southeast of a dry creek bed. The soit in the site area is a grayish brown, sandy loam. The predominant vegetation in the site vicinity is prickly pear, thorny brush, and low mesquite shrubs. Occasional small junipers are also scattered along the ridge. 
Artifacts Recovered: Three interior flakes, 2 primary cortex flakes, 3 secondary cortex flakes.

Description: 41 WB 70, like 41 WB 67, was probably a flintworking location, that was briefly occupied. An absence of burned rock and the low density of cultural debris supports this interpretation. It is roughily ovoid in shape and is approximately 40 meters long (east to west) by 25 meters wide (north to south).

Probable Cultural Associations: Unknown.

Condition: Severely disturbed by root plowing within the last 5 years.

Recommendations: The reconnaissance team collected al1 of the artifacts observed in the site vicinity. There is no evidence of buried, undisturbed, cultural deposits. No further work is recommended.

SITE: 41 WB 71

Environmental Location: This site is located on the north slope of a low ridge approximately 100 meters southeast of a dry creek bed. It is on the north side of the same ridge 41 WB 70 is located on. The distance between these two sites is approximately 120 meters. The soil in the site area is a grayish brown, sandy loam. The predominant vegetation in the site area is prickly pear, thorny brush, and low mesquite shrubs.

Artifacts Recovered: Three thick bifaces, 2 thin bifaces, 1 core tool/chopper, 3 cores, 6 flakes with edge modification, 102 interior flakes, 16 primary cortex flakes, 5 projectile points, 4 scrapers, 36 secondary cortex flakes, 7 unifaces, 4 utilized flakes.

Description: In terms of sheer numbers of artifacts, no other site found during the project approaches 41 WB 71 . A number of fire-cracked and burned rocks was also observed in the site vicinity. This site was probably a large residential base camp, that featured such activity areas as hearths, lithic workshops, plant processing areas, butchering locations, etc. The site is irregular in shape and covers ca. $100 \mathrm{~m}^{2}$.

Probable Cultural Associations: Several formal artifact types were recovered and can best be presented in the following table: 
TABLE 4. PROBABLE CULTURAL ASSOCIATION OF FORMAL ARTIFACT TYPES RECOVERED FROM 41 WB 71.

Numbers of Artifact Types

3 Desmuke projectile points

1 oemos biface

1 Nueces scraper

2 Tortugas projectile points
Associated Cultural/Historical Period

Middle Archaic (?)

Late Archaic

Middle to Late Archaic

Middle Archaic (?)

The Olmos biface (Fig. 2,c) and Nueces scraper (Fig. 2,f) types have not been we11 dated (Hester, White and White 1969; Shafer and Hester 1971). However, they are generally considered to be Archaic period artifacts that may persist, especially in the case of the Olmos bifaces, into the Late Prehistoric period. These artifacts are considered again in the Summary and Conclusions section of this report.

Condition: Severely disturbed by root plowing within the last 5 years.

Recommendations: This site was totally collected of a11 artifacts observed on the ground surface. An auger test (see below) failed to reveal any evidence of buried, undisturbed cultural deposits. No further work is recommended.

Additional Remarks: An auger test to a depth of $75 \mathrm{~cm}$ revealed the upper $60 \mathrm{~cm}$ to be a disturbed strata underlain by a dark red calcareous clay. No artifacts were recovered $10 \mathrm{~cm}$ below surface.

\section{SITE: 41 WB 72}

Environmental Location: This site is situated on the north slope of a hil1top located 800 meters south of a dry creek bed. It is the same dry creek bed that is nearest to 41 WB 70 and 71 . The soil is a reddish brown, sandy loam. The vegetation around 41 WB 72 consists primarily of thorny brush and prickly pear.

Artifacts Recovered: Five interior flakes, 2 primary cortex flakes, 7 secondary cortex flakes.

Description: Like 41 WB 67 and 41 WB 70 this site was probably a flintworking location, that was briefly occupied. Again, an absence of burned rock and the low density of cultural debris would support such an interpretation. The site is roughly circular and covers approximately $12 \mathrm{~m}^{2}$.

Probable Cultural Associations: Unknown. 
Condition: Severely disturbed by root plowing and bulldozing within the last 5 years.

Recommendations: All of the artifacts were collected from the surface of this site. There was no evidence of buried, undisturbed cultural deposits. No further work is recommended.

Additional Remarks: Two isolated flakes were found ca. $600 \mathrm{~m}$ south of 41 WB 72. PossibTy these artifacts represent brief prehistoric activities.

\section{SITE: 41 WB 73}

Environmental Location: This site is located on a ridge top approximately 400 meters south of a dry creek bed. The soil is a reddish brown, sandy loam containing numerous limestone gravels, pebbles and cobbles. The vegetation on this ridge consists primarily of thick growths of mesquite and thorny brush.

Artifacts Recovered: One core fragment, 2 core tools/choppers, 2 hammerstones, 7 interior flake, 2 primary cortex flakes, 1 projectile point, 5 secondary cortex flakes.

Description: A scatter of burned and fire-cracked rocks on the site in conjunction with the assemblage described above suggests this site was probably a field camp, where various hunting and flintworking activities took place. It is roughly ovoid in shape and approximately 70 meters long (east to west) by 40 meters wide (north to south).

Probable Cultural Associations: The projectile point recovered from this site (Fig. 3,a) has a broken base. However, it was probably stemmed, assigning it to a general Archaic period association (possibly Middle to Late Archaic).

Condition: Slightly disturbed by root plowing within the last 20 years.

Recommendations: This site was totally surface collected. There was no indication of buried, undisturbed, cultural deposits. Further work is not recommended.

Additional Remarks: Between 41 WB 72 and 73, on the edge of the dry creek bed nearest 4T WB 73, an isolated biface and two isolated interior flakes were found in an area of $400 \mathrm{~m}^{2}$. Possibly these artifacts indicate very brief prehistoric activities. 
SITE: 41 WB 74

Environmental Location: This site is located on a hilltop approximately 300 meters south of a dry creek bed. It is the same dry creek bed that is located north of 41 WB 73. The soil is a grayish brown, sandy loam containing large amounts of 1 imestone gravels, pebbles, and cobbles. Mesquite trees dominate the areal vegetation. Some thorny brush and prickly pear occur in the site vicinity also.

Artifacts Recovered: Only diagnostic artifacts were collected; 2 thin bifaces, 1 thick biface, 4 projectile points, 1 uniface (see Figs. 3,b-f).

Description: Artifacts observed but not collected from 41 WB 74 include numerous fTakes of every category, core tools/choppers, hammerstones, and utilized flakes. Also, a quantity of burned and fire-cracked rock was observed in scatters across the site surface. These data suggest that 41 WB 74 was a residential base camp, similar perhaps to $41 \mathrm{WB} 71$. The site is irregular in shape and covers an area greater than $80 \mathrm{~m}^{2}$.

Probable Cultural Associations: of the projectile points; two were of the Tortugas type (Fig. 3,e) and have possible Middle Archaic associations. One projectile point is an Abasolo (Fig. 3,f) specimen which is roughly dated to 5000/3000 B.C. (Suhm and Jelks 1962:165), but may persist later. The other projectile point is a small, triangular type that is difficult to identify with any certainty (Fig. 3,c).

Condition: Moderately disturbed by root plowing within the last 20 years.

Recommendations: Since 41 WB 74 is outside of the proposed mining area, no further work is recommended at this time. If it is to be in a mining area in the future, it is recommended that the site be totally collected before mining begins.

SITE: $\quad 41$ WB 75

Environmental Location: This site is situated on the west slope of the hilttop where $47 \mathrm{WB} 74$ is located. It is approximately 400 meters south of the same dry creek bed as 41 WB 74 and 41 WB 73 . The soil is a grayish brown, sandy loam with numerous limestone gravels and pebbles scattered through it. The predominant vegetation in the site locale is mesquite trees, thorny brush, prickly pear and short grasses.

Artifacts Recovered: No diagnostic artifacts were observed or collected. Seven flakes of various kinds were observed on the site. 
Description: Like 41 WB 67, 41 WB 70, and 41 WB 72 this site was probably a flintworking location that was briefly occupied. No burned or fire-cracked rock was found in the site vicinity. The site is irregularly shaped and covers about $10 \mathrm{~m}^{2}$.

Probable Cultural Associations: Unknown.

Condition: Badly disturbed by root plowing and bulldozing within the last 5 years.

Recommendations: The same factors hold as those described for 41 WB 74 with the same recommendations.

SITE: 41 WB 76

Environmental Location: This site is on the west slope of a hilltop, approximately 400 meters south of a dry creek bed. A pond is located approximately 400 meters northeast of the site. The soil in the site area is a grayish brown, sandy loam. Vegetation in the site area is predominantly short grasses and low growths of thorny brush.

Artifacts Recovered: Three bifaces (Fig. $3, g$ ), 2 projectile points, and 1 scraper. Artifacts observed were flakes of all kinds, unifaces, utilized flakes, etc. Additionally, a scatter of fire-cracked burned rock was seen throughout the site area. The projectile points were 1 broken Tortugas and 1 Abasolo (Fig. 3,h).

Description: 41 WB 76 was probably a residential base camp, similar to 41 WB 71 and 41 WB 74 . However, it has smaller amounts of cultural debris and may have been occupied less intensively than 41 WB 71 and 41 WB 74 . This site was ovoid in shape and covered approximately $60 \mathrm{~m}^{2}$.

Probable Cultural Associations: Archaic.

Condition: Badly disturbed by root plowing within the last 10 years.

Recommendations: See 41 WB 74.

SITE: 41 WB 77

Environmental Location: This site is located on a long ridge approximately 300 meters south of a dry stream bed. The soil in the site area is a reddish 
brown, sandy loam. Cryptocrystalline silicate gravels, pebbles and cobbles are eroding from this surface. Vegetation in the site area is characterized by dense thickets of thorny brush, mesquite, and scattered prickiy pear.

Artifacts Recovered: Two cores were collected. Artifacts observed in the site vicinity included various primary cortex, secondary cortex and interior flakes as well as several cores in various stages of reduction. No firecracked or burned rocks were observed.

Description: Based on the scatter of cores, flintworking debitage, and abundant raw material observed on this site 41 WB 77 appears to be an extractive location where cryptocrystalline silicate material was procured and modified.

Probable Cultural Associations: Unknown.

Condition: Badly disturbed by root plowing within the last 10 years.

Recommendations: See 41 WB 74.

SITE: 41 WB 78

Environmental Location: This site is located on the south slope of a low ridge, approximately 100 meters south of a dry creek bed. The soil in the site vicinity is a reddish brown, sandy loam. Cryptocrystalline silicate gravels, pebbles, and cobbles are eroding from this ridge. Vegetation consists of dense thickets of thorny brush, mesquite, and scattered prickly pear.

Artifacts Recovered: No diagnostic artifacts were observed or collected. Artifacts observed included a scatter of primary cortex, secondary cortex, interior flakes and cores in various stages of reduction. No fire-cracked or burned rocks were observed.

Description: Like 41 WB 77, this site was probably a location where cryptocrystalline silicate raw material was acquired and modified.

Probable Cultural Associations: Unknown.

Condition: Badly disturbed by root plowing within the last 10 years.

Recommendations: See 41 WB 74. 


\section{SUMMARY AND CONCLUSIONS}

The major conclusions derived from the reconnaissance project regarding the principal activities performed at, and the primary prehistoric functions of, the Santonino sites are as follows (see Table 5):

Sites 41 WB 67, 70, 72 and 75 with their absence of fire-cracked rock, forma 1 tools, and low amounts of cryptocrystalline silica debitage were used briefly by people of unknown cultural/historical association(s). Furthermore, these sites functioned as flintworking locations.

Sites 41 WB 77 and 78 were probably visited intermittently, again by people of unknown cultural/historical associations. An absence of such occupational debris as fire-cracked or burned rocks suggests these visits were brief and that these two sites functioned as locations where lithic raw material was acquired and initially modified for transport to field or residential base camps.

Site 41 WB 68, with its presence of fire-burned and cracked rock served as a field camp. The presence of a scraper and a few utilized flakes suggests that perhaps butchering, hideworking, tool maintenance, and/or replacement of tools occurred. The low number of these artifacts indicates the occupation was brief. A cultural/historical period association cannot be offered because of a lack of diagnostic artifacts from this site.

Site 41 WB 69, with its presence of fire-burned and cracked rock was a field camp. The hammerstone and various flakes recovered suggest that tool maintenance and/or modification occurred here. Additionaliy, the presence of the uniface and two projectile points indicates that other hunting activities took place; perhaps projectile point replacement, haft repair or possibly skinning and butchering of animals. The low amounts of all of these artifacts suggest the camps were occupied briefly. The Desmuke projectile points are generally associated with the Archaic period and may be Middle Archaic in age.

Site 41 WB 71, with its large amount of cultural debris (artifacts and firecracked and burned rock), was probably a large residential base camp where a variety of hunting, food preparing, hideworking, etc., activities occurred. This site because of unknown favorable prehistoric environmental factors (which remain problematic) may have been occupied repeatediy over a number of seasons. Proximity to a water source may have been one favorable environmental condition. The diagnostic artifacts recovered from 41 WB 71 suggest it was occupied during the Archaic period (see Chronology section, page 26).

The cultural debris from 41 WB 73 consists of various artifacts associated with flintworking activities: a scatter of fire-burned and cracked rocks, chopping tools and a stemmed projectile point with a broken base. These artifacts in their low numbers are indicators of activities (tool maintenance/manufacture, butchering, etc.) associated with a hunting camp that was occupied briefly. The stemmed point cannot be confidently "typed" because most of the base is missing, but it possibly dates from the Archaic period. 
TABLE 5. SANTONINO PROJECT SITE TYPES, THEIR INTENSITY OF OCCUPATION, DIAGNOSTIC ARTIFACTS AND ASSOCIATED CULTURAL/HISTORICAL PERIODS.

\begin{tabular}{|c|c|c|c|c|}
\hline Site & Type & $\begin{array}{l}\text { Probable Degree } \\
\text { of Occupation }\end{array}$ & $\begin{array}{l}\text { Diagnostic } \\
\text { Artifacts } \\
\text { Recovered } \\
\end{array}$ & $\begin{array}{l}\text { General } \\
\text { Cultural/Historical } \\
\text { Period Association } \\
\end{array}$ \\
\hline 41 WB 67 & $\begin{array}{l}\text { flintworking } \\
\text { location }\end{array}$ & brief & none & unknown \\
\hline 41 WB 68 & field camp & brief & none & unknown \\
\hline 41 WB 69 & field camp & brief & $\begin{array}{l}2 \text { Desmuke pro- } \\
\text { jectile points }\end{array}$ & Archaic \\
\hline 41 WB 70 & $\begin{array}{l}\text { flintworking } \\
\text { location }\end{array}$ & brief & none & unknown \\
\hline 41 WB 71 & $\begin{array}{l}\text { residential } \\
\text { base camp }\end{array}$ & $\begin{array}{l}\text { longer-term } \\
\text { (possibly } \\
\text { occupied } \\
\text { repeatedly or } \\
\text { seasonally) }\end{array}$ & $\begin{array}{l}3 \text { Desmuke and } \\
2 \text { Tortugas pro- } \\
\text { jectile points, } \\
1 \text { Oemos biface, } \\
1 \text { Nueces scraper }\end{array}$ & $\begin{array}{l}\text { Archaic to } \\
\text { Late Archaic }\end{array}$ \\
\hline 41 WB 72 & $\begin{array}{l}\text { flintworking } \\
\text { location }\end{array}$ & brief & none & unknown \\
\hline 41 WB 73 & field camp & brief & 1 projectile point & Archaic \\
\hline 41 WB 74 & $\begin{array}{l}\text { residential } \\
\text { base camp }\end{array}$ & $\begin{array}{l}\text { longer-term } \\
\text { (possibly } \\
\text { occupied } \\
\text { repeatedly or } \\
\text { seasonally) }\end{array}$ & $\begin{array}{l}2 \text { Tortugas and } \\
1 \text { Abasolo pro- } \\
\text { jectile point }\end{array}$ & $\begin{array}{l}\text { Archaic to } \\
\text { Late Archaic }\end{array}$ \\
\hline 41 WB 75 & $\begin{array}{l}\text { flintworking } \\
\text { location }\end{array}$ & brief & none & unknown \\
\hline 41 WB 76 & $\begin{array}{l}\text { residential } \\
\text { base camp }\end{array}$ & longer-term & $\begin{array}{l}1 \text { Abasolo and } \\
1 \text { Tortugas pro- } \\
\text { jectile point }\end{array}$ & $\begin{array}{l}\text { Archaic to } \\
\text { Late Archaic }\end{array}$ \\
\hline 41 WB 77 & $\begin{array}{l}\text { flintworking } \\
\text { location }\end{array}$ & $\begin{array}{l}\text { possibly visited } \\
\text { intermittently }\end{array}$ & none & unknown \\
\hline 41 WB 78 & $\begin{array}{l}\text { flintworking } \\
\text { location }\end{array}$ & $\begin{array}{l}\text { possibly visited } \\
\text { intermittently }\end{array}$ & none & unknown \\
\hline
\end{tabular}


Site 41 WB 74 was probably like 41 WB 71, a large residential base camp that may have been occupied repeatedly or seasonally. The diagnostic artifacts recovered from 41 WB 74 (2 Tortugas and 1 Abasolo projectile points) are generally associated with the Archaic period.

The third residential base camp in the project area was 41 WB 76 . However, it had significantly less cultural debris than either 41 WB 71 or 41 WB 74 . Thus, it may have been occupied less frequently or possibly only once for a few months during a season. The artifacts recovered from 41 WB 76 indicates that it was probably occupied during the Archaic to Late Archaic period.

\section{Chronology}

In reading over the preceding section, it is apparent that exact, confident, chronological placement of these sites is limited to very tenuous statements. As discussed in the "Chronology of Prehistoric Occupation" section of this report, the internal sequence of the Archaic period is still problematic to south Texas prehistory. The reason the Pre-Archaic and Archaic periods are discussed in provisional terms is because good radiocarbon dates from well stratified Archaic sites in south Texas have not been obtained.

In order to present more informed chronological perspective for extreme southern Texas, I discussed certain diagnostic artifacts recovered from the Santonino Project with Grant Hall, project director of the CAR's Nueces River Project. Similar artifacts have been excavated in buried sites from the Nueces River Project area. Interpretations are tentative until the conclusion of the Nueces River Project analyses. Firm chronological placement of the Tortugas, Desmuke, and Abasolo projectile points is still pending in this area, but their cultural/historical associations will hopefully be refined by the work in the Frio River region (Hall, personal communication). Regarding the olmos biface and the Nueces scraper, evidence from the Choke Canyon area presently suggests they are from the Late Archaic period (Hall, personal communication). Thus, 41 WB 71 was probably occupied during the Late Archaic and may have been occupied earlier.

\section{Regional Comparisons}

Comparisons of the Santonino Project area to other regions in south Texas is difficult for the following reasons: (1) a lack of published information from other areas; and (2) in areas where archaeological research has been conducted and the results published, the environmental conditions in these areas are very different from those in the Santonino vicinity.

Nunley's work from the Falcon Reservoir area dealt with the Rio Grande River. This region with its "breaks of the Rio Grande," alluvial plains, terraces, and tributary creeks that flow year round is quite different from the rolling hills and uplands of the Santonino region. A slight change in the water table in the Santonino area would probably be more disruptive to the prehistoric environment than in the Rio Grande plain. Thus, these two areas are not strictly 
comparable. However, in terms of geographical proximity the "Santa Isabel" and "Arroyo Gato" hypothetical sociocultural units of Nunley are closest to the Santonino area (Nunley 1971:357).

In considering the Santa Isabel unit, the significant unifacial tool type, an assymmetrical ovate with cortex, was present in the Santonino area. However, the significant bifacial tool type, stemmed projectile points, was present only at 41 WB 73. Therefore, as a whole, the Santa Isabel unit is not well represented in the Santonino Project region.

The Arroyo Gato unit, as hypothesized by Nunley, has some of the following salient characteristics (ibid.:368):

Dominant lithic technology: Flake modification.

Significant bifacial tool types:. . Abasolo-Catán points; beveled Tortugas points.

Flake modification does not appear to be the dominant lithic technology in the Santonino area; core reduction into bifaces seems to be equally important. Certainly Abasolo points are present, but no beveled Tortugas points were found in the project area. I would conclude that the Arroyo Gato unit (as well as Nunley's other three units) does not characterize the cultural debris recovered from the Santonino project.

In Starr County, Nunley and Hester (1975) located 52 archaeological sites along stretches of the Arroyo Los 01 mos system. A11 of the sites were located in the lomeria or hilly territory between the arroyo and uplands. Two site types, gallery and bower, were based on locational distinctions (Nunley and Hester 1975:13-14). Gallery referred to sites situated on terraces adjacent to arroyos. Bower referred to sites located in upland areas overlooking the drainage and the landforms where gallery sites were located.

Thirty-six of these 52 sites were attributed to brief occupation. Three sites were considered to represent long-term occupation areas and ten other sites were Tithic workshops. No evidence of Late Prehistoric occupation was found. Only one site had a possible Paleo-Indian component (ibid.). The area was characterized predominantly by Archaic occupations. In genera7, these characteristics are very similar to the results of the Santonino project which has evidence of intensive Archaic period occupations.

However, Nunley and Hester could not derive a general settlement distribution scheme that would apply to the region. Our results in the Santonino area by contrast show that the sites are distributed on slopes, hilltops, or ridges located south of dry creek beds. These locations are generally similar to the bower sites described by Nunley and Hester (1975).

Applicability of Recent Models of Prehistoric Hunter-Gatherer Adaptive Systems to Santonino Data

Jochim (1976:13) has diagrammed the generalized hunter-gatherer subsistence system: 


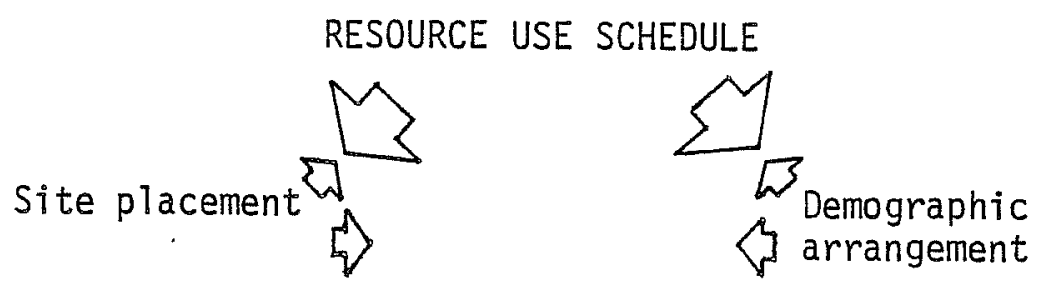

The basic assumption is that the determination of resource use tends to precede and condition the site placements and demographic arrangements of a hunter-gatherer group. The operation of influences in the reverse direction as well as that of factors independent of resource use are not ignored, but receive secondary consideration.

Another assumption that Jochim (ibid.) and Binford (1980) make is that ethnographic analogy can be used to understand prehistoric cultural processes. This assumption is not always well supported as Hester (1976:87) writes:

Will it be possible to formulate models for regional research by extrapolating from "arid land hunters and gatherers" in similar environments around the world? Perhaps this will be of some value. But here I would inject a warning, stemming from the lack of paleoenvironmental information.

Clearly this is a problem, and with this warning in mind, I will procede with this discussion.

Jochim (1976:18) has 1isted the major decisions that confront any huntergatherer group as:

1. Which resources should be used?

2. How much of each resource should be used?

3. When should each resource be used?

4. Where should the resource be procured?

5. How many people can and should procure the resources?

Binford (1980:10) has further defined hunter-gatherer subsistence and settlement into two basic types "foragers" and "collectors". Within Binford's conceptualization, Santonino-area hunter-gatherers would appear to have been collectors because they probably were hunters "who supply themselves with specific resources through specially organized task groups". In order to demonstrate this hypothetical adaptation in the project area, Binford's model needs to be defined in terms of its components.

If the technoenvironmental adaptation was of the forager mode, one would expect the following types of sites with the associated criteria for their identification and placement (Binford 1980:9 and Table 6): 
TABLE 6. COMPONENTS OF BINFORD'S FORAGER MODEL FOR HUNTER-GATHERERS.

\begin{tabular}{|c|c|c|}
\hline Sites & Definition & Archaeological I.D. Criteria \\
\hline Residential Base & $\begin{array}{l}\text { Center of subsistence ac- } \\
\text { tivities where most pro- } \\
\text { cessing, manufacturing } \\
\text { and maintenance activi- } \\
\text { ties take place. Short } \\
\text { term in forager mode. } \\
\text { Longer term in collector } \\
\text { mode. }\end{array}$ & $\begin{array}{l}\text { Features, consisting of } \\
\text { hearths, lithic workshops, } \\
\text { ground stone tools for } \\
\text { plant processing, mixture } \\
\text { of diverse floral and faunal } \\
\text { remains. Depth of deposit } \\
\text { would be minimal due to } \\
\text { brief occupation. }\end{array}$ \\
\hline Location & $\begin{array}{l}\text { Where extractive activi- } \\
\text { ties are exclusively con- } \\
\text { ducted, low-bulk procure- } \\
\text { ment. Very brief usage. }\end{array}$ & $\begin{array}{l}\text { Difficult to identify due } \\
\text { to brief occupation and low } \\
\text { bulk extraction, possibly } \\
\text { some modified fioral mate- } \\
\text { rials and remains (Binford } \\
1980: 9 \text { ). No hearths or evi- } \\
\text { dence of long term occupa- } \\
\text { tion would be present. }\end{array}$ \\
\hline
\end{tabular}

In addition to the two types of sites described above, if the hunter-gatherer group were collectors, one would expect the following types of sites with their associated criteria for identification (Binford 1980:10-13 and Table 7):

TABLE 7. COMPONENTS OF BINFORD'S COLLECTOR MODEL FOR HUNTER-GATHERERS.

Sites

Field camp

Station
Definition

Temporary occupationa 1 center for a task group which maintains itself while away from the residential base. Field camps may be expected to be further differentiated by specialized tools and the nature of the target resources, thus caribou hunting camps, fishing camps, mastodon hunting camps, etc.

Where special-purpose task groups are localized in information gathering, i.e. game movement, may be ambush locations or hunting stands.
Archaeological I.D. Criteria

Small discrete scatter of cultural debris, firecracked rock from hearth, flakes from tool maintenance, and abundance of one kind of fauna. Lost or discarded specialized tools.

Minimal to low cultural debris and faunal remains, etc., if associated nearby with a field camp I.D. of station may be facilitated. 
TABLE 7. (continued)

Sites

Definition

Archaeological I.D. Criteria

Cache

Common components of a logistical strategy i.e. successful procurement of resources by relatively large groups generally means large bulk. This bulk must be transported to consumers, temporary storage is required.

Such field storage facilities may be constructed to deal specifically with the bulk obtained.

Evidence of large bulk processing large amounts of split bone, discarded tools, butchering marks on the bone, storage features, pits, racks, platforms, etc. (evidence of postholes).

Within each site type one can expect further variability to relate to season and to the character of the resource targets of such logistically organized task groups. An additional source of variability is that all of the functions may not necessarily be independently located. As Binford (1980:12) notes, "In some situations one might be able to use the field camp as an observation point, in others, it may equally serve as a hunting stand. Many other combinations can be imagined. The point is simple, the greater the number of possible combinations, the greater the range of intersite variability which we may expect". The last point is very important. Evidence of contemporaneous, extensive, intersite variability indicates the collector mode of hunter-gatherer subsistence.

I would suggest that such evidence of extensive intersite variability is present in the Santonino vicinity. This variability has been described in the preceding section and is also present in Table 7 which is based on Binford's identification criteria. Additionally, Table 8 summarizes the cultural system variety as evidenced in the project area.

TABLE 8. CULTURAL SYSTEM VARIETY IN SANTONINO PROJECT AREA (DERIVED FROM PROJECT DATA, HESTER 1980 AND NUNLEY 1971).

Tool Kit Variety

Settlement Pattern Variety

Subsistence Variety

Lithic Acquisition Variety

Lithic Typological Variety high variety, many different functional categories

high, many different functiona? site types in varied environmental settings

high; wide range of food sources used (Nunley 1971; Hester 1980)

low, cryptocrystalline focus moderate; possible to define regional lithic traditions with diagnostics; probable slow change in artifact types 
The extent of intersite variability is difficult to assess in the Santonino region for the same reasons that Jochim's questions cannot be confidentiy answered. Due to extensive site disturbances and lack of preserved organic materials, we cannot determine what specific resources were exploited by these Archaic hunter-gatherers. Therefore cache sites cannot be identified. Some of the field camps may have doubled as stations (possibly 41 WB 69 and 73), but because of the severe disturbance these sites have suffered, separate functional activity areas cannot be discerned. The same can be said for all of the Santonino Project sites. Additionally, many of the isolated artifact finds were probably extractive locations of one kind or another but any further assessment is problematic.

In summary, the hypothesis can be made that these sites were occupied during periods when surface water was readily available, probably during one or more wet climatic oscillations of the Archaic period. Furthermore, one could speculate that, based on the provisional chronological placement of the Desmuke and Abasolo projectile points, these occupations occurred sometime during the interval between 5000 to 1000 B.C. If one proposes that the paleoclimatic conditions, suggested by Dillehay (1974), were also conditions present in south Texas, then the Santonino region may not have been intensively occupied during the periods 5800 to 3200 B.C. and/or after 1000 B.C. This proposition would narrow the Santonino occupational time depth from 3200 B.C. to approximately 1000 B.C.; and this would be the limit of provisional speculation.

Perhaps during this hypothetical interval (in reference to Jochim's series of decisions outlined above) the prehistoric inhabitants of the region made some of the following decisions: (1) to hunt certain fauna (deer, bison, etc.); (2) to kill them at specific locations; and (3) to butcher them through coordinated activities. Similar plant gathering decisions were probably made as we17.

In assessing the applicability of Binford's and Jochim's models to the Santonino area, the same problems apply as those described in the chronology section of this report. These interpretations must be tentative until buried sites with preserved organic and paleoenvironmental remains are located, excavated, and radiocarbon dated. Obviously there is a need for such research to be proposed and conducted. Studies of this sort, that examine different human experiences in different temporal and spatial contexts, can contribute to the testing and formulation of predictive models and provide a basis for the further refinement of archaeological methods.

In conclusion, it is hoped that the data in this report will be used by future researchers to plan for the management of archaeological resources in Webb County and that many of the problems discussed in this report will be addressed and eventually resolved. Though the results of the project described in this report are tentative, it is felt that the project area has been adequately studied. No further work is necessary to protect those sites in the area of proposed uranium mining. 


\section{REFERENCES CITED}

Adovasio, J. M., J. D. Gunn, J. Donahue and R. Stuckenrath

1978 Meadowcroft Rockshelter, 1977: An Overview. American Antiquity 43:632-651.

Adovasio, J. M., J. D. Gunn, J. Donahue, R. Stuckenrath, J. E. Guilday and K. Vol Iman

1980 Yes, Virginia, It Rea11y Is That 01d: A Repiy to Haynes and Meade. American Antiquity 45:588-595.

Beasley, T. S.

1978 A Late Prehistoric Site in Webb County, Texas. La Tierra 5(2):2-9.

Binford, L. R.

1980 Willow Snake and Dog's Tails: Hunter-Gatherer Settlement Systems and Archaeological Site Formations. American Antiquity 45(1):4-20.

Blair, F.W.

1950 The Biotic Provinces of Texas. Texas Journal of Science 2(1):93-117.

Bryant, V. M., Jr.

1969 Late Full-Glacial and Post-Glacial Pollen Analysis of Texas Sediments. Ph.D. Dissertation, The University of Texas at Austin.

Bryant, V. M., Jr. and H. J. Shafer

1977 The Late Quaternary Paleoenvironment of Texas: A Model for the Archeologist. Bulletin of the Texas Archeological Society 48:1-26.

Dibble, D. S. and D. Lorrain

1967 Bonfire Shelter: A Stratified Bison Ki11 Site, Val Verde County, Texas. Texas Memorial Museum, Miscellaneous Papers 1.

Dillehay, T. D.

1974 Late Quaternary Bison Population Changes on the Southern PTain. Plains Anthropologist 19:180-196.

Epstein, F. J.

1975 Some Reflections on the Nature of the Northeast Mexico Lithic Tradition and the Problem of its Origin. Paper presented at the Conference on the Prehistory of Northeastern Mexico, Monterrey, Nuevo Leon, Mexico. 
Fenneman, N. M.

1931 Physiography of the western united States. McGraw-Hi11, New York. Flannery, K. V.

1976 The Early Mesoamerican Village. Academic Press, New York. Fox, D. E.

1978a Archaeological Monitoring and Testing for Building Construction and Landscaping on the Site of Fort McIntosh, Laredo, Texas. Letter report, Center for Archaeological Research, The University of Texas at San Antonio to Laredo Junior College.

1978b Archaeological Testing for Construction of an Office Building on The Site of Fort McIntosh, Laredo, Texas. Letter report, Center for Archaeological Research, The University of Texas at San Antonio, to Laredo State University.

1979 Archaeological Testing at Fort McIntosh, Laredo Junior College Campus, Laredo, Texas. Center for Archaeological Research. The University of Texas at San Antonio, Archaeological Survey Report 68.

Fox, D. E. and H. G. Uecker

1977 An Archaeological Study of the McPherson Road Project Laredo, Texas. Center for Archaeological Research. The University of Texas at San Antonio, Archaeological Survey Report 45.

Gagliano, S. M.

1967 Occupation at Avery Island. Louisiana State University Press, Baton Rouge, Louisiana.

Gibson, E. C.

1980 Archaeological Investigations at Angus Flats, Pecos County, Texas. Center for Archaeological Research. The University of Texas at San Antonio, Archaeological Survey Report 99.

Gunn, J. D. and F. Weir

1976 Tool Kit Hypotheses: A Case of Numerical Induction. Lithic Technology 3(5):137-135.

Ha11, G. D.

1973 Report of Archaeological Investigations: Zacate Creek Flood Control Project, Laredo, Texas. Texas Archeological Survey, The University of Texas at Austin. 
Hester, T. R.

1975 A Chronological Overview of Prehistoric Southern and South-Central Texas. Paper presented at the Conference on the Prehistory of Northeastern Mexico, Monterrey, Nuevo Leon, Mexico.

1976 Late Pleistocene Aboriginal Adaptations in Texas. In Papers on Paleo-Indian Archaeology in Texas:1. Center for Archaeological Research, The university of Texas at San Antonio, Special Repont 3.

1977 The Current Status of Paleo-Indian Studies in Southern Texas and Northeastern Mexico. In Paleo-Indian Lifeways, E. Johnson (ed.). The Museum Journal XVII. West Texas Museum Association, Texas Tech University, Lubbock.

1978 Background to the Archaeology of Chaparrosa Ranch, Southern Texas. Center for Archaeological Research, The University of Texas at San Antonio, Special Report 6(1).

1979 Early Populations in Prehistoric Texas. Archaeology 6(32):26-33.

1980 Digging into South Texas Prehistory. Corona, San Antonio, Texas. Hester, T. R., R. F. Heizer and J.A. Graham

1975 Field Methods in Archaeology. 6th Edition. Mayfield Publishing Company, Palo Alto, California.

Hester, T. R., L. D. White and J. White

1969 Archaeological Materials from the Oulline Site (41 LS 3) and Other Sites in La Salle County, Southwest Texas. Texas Journal of Science $21(2): 130-165$.

Inglis, J. M.

1964 A History of Vegetation on the Rio Grande Plain. Texas Parks and Wildlife Department Bulletin 45.

Ivey, J. E., T. Medlin and J. D. Eaton

1977 An Initial Archaeological Assessment of Areas Proposed for Modification at Fort McIntosh, Webb County, Texas. Center for Archaeological Research. The University of Texas at San Antonio, Archaeological Survey Report 32.

Jennings, J. D.

1974 Prehistory of North America. McGraw-Hil1, New York. 
Jochim, M. A.

1976 Hunter-Gatherer Subsistence and Settlement: A Predictive Model. Academic Press, New York.

Johnson, L., Jr.

1964 The Devil's Mouth Site: A Stratified Campsite at Amistad Reservoir, Val Verde County, Texas. Department of Anthropology. The University of Texas at Austin, Archeology Series 6.

Kelley, J. C.

1959 The Desert Cultures and the Balcones Phase: Archaic Manifestations in the Southwest and Texas. American Antiquity 24(7):319-322.

Kelly, T. C.

1979 An Archaeological Reconnaissance of the Palafox Mining Area, Webb County, Southern Texas. Center for Archaeological Research, The university of Texas at San Antonio, Archaeological Survey Report 71 .

Krieger, A. D.

1964 Early Man in the New World. In Prehistoric Man in the New World. J. D. Jennings and E. Norbeck (eds.) pp. 23-87, University of Chicago Press.

Mallouf, R. J., B. J. Baskin and K. L. Killen

1977 A Predictive Assessment of Cultural Resources in Hidalgo and Willacy Counties, Texas. Texas Historical Commission, Office of the State Archeologist, Survey Repart 23.

Marmaduke, W. S.

1978 Prehistory at Bear Creek, Brewster County, Texas. Texas Historical Commission, Office of the State Archeologist, Survey Report 25.

Med7 in, T.

1977a Archaeological Testing for Proposed Water/Sewer Line Ditch on Fort McIntosh, Laredo, Texas. Letter report, Center for Archaeologica 1 Research, The University of Texas at San Antonio, to Laredo State University.

1977b A Preliminary Report on Archaeological Testing at Fort McIntosh, Laredo Junior College Campus, Laredo, Texas. Letter report, Center for Archaeological Research, The University of Texas at San Antonio, to Laredo Junior College. 
Montgomery, J. L.

1978 The Mariposa Site: A Late Prehistoric Site on the Rio Grande Plain of Texas. Center for Archaeological Research, The University of Texas at San Antonio, Special Report 6(2).

Nunley, J. P.

1971 Sociocultural Units of the Southwestern Texas Archaic: An Analytic Approach, Ph.D. Dissertation. Southern Methodist University. University Microfilms, Ann Arbor.

Nunley, J. P. and T. R. Hester

1975 An Assessment of Archaeological Resources in Portions of Starr County, Texas. Center for Archaeological Research. The University of Texas at San Antonio, Archaeological Survey Report 7.

Oldfield, F. and J. Schoenwetter

1975 Discussion of Pollen-Analytical Evidence. F. Wendorf and J. Hester, eds., In Late Pleistocene Environments of the Southern High Plains. Fort Burgwin Research Center, Rancho de Taos, New Mexico.

Robinson, R. L.

1979 Biosilica and Climatic Change at 41 GD 21 and 41 GD 21A. Appendix IV in Archaeological Investigations of Two Prehistoric Sites on the Coleto Creek Drainage, Goliad County, Texas, by D. Fox. Center for Archaeological Research. The University of Texas at San Antonio, Archaeological Survey Report 69.

Saunders, J. T.

1976 An Archaeological Survey Along a Portion of the Santa Isabella Creek in Webb County, Texas. Manuscript on file at the Center for Archaeological Research, The University of Texas at San Antonio.

Saunders, J. T. and E. L. Saunders

1978 A Ranch Survey in the Upper Santa Isabel1a Creek Watershed, Webb County, Texas. La Tierra 5(1):2-18.

Shafer, H. J. and T. R. Hester

1971 A Study of the Function and Technology of Certain Bifacial Tools from Southern Texas. Texas Historical Survey Committee, Archaeological Report 20. 
Shiner, J. R.

1969 Component Analysis for Archaic Sites. Bulletin of the Texas Archeological Society 40:215-230.

Sollberger, J. B. and T. R. Hester

1972 The Strohacker Site: A Review of Pre-Archaic Manifestations in Texas. Plains Anthropologist 1(58):326-344.

Story, D. A.

n.d. Adaptive Strategies of Archaic Cultures of the West Gulf Coastal Plain. Manuscript on file with Author.

Suhm, D. A. and E. B. JeTks

1962 Handbook of Texas Archeology: Type Descriptions. Texas Archeological Society and Texas Memorial Museum, Bulletin 4, Austin.

Weir, F. A.

1976 The Central Texas Archaic, Ph.D. Dissertation. Washington State University, Pullman, Washington. 
